\title{
Chenodeoxycholic acid increases the induction of CYP1A1 in HepG2 and H4IIE cells
}

\author{
ZEIN SHABAN IBRAHIM ${ }^{1,2}$ \\ ${ }^{1}$ Department of Physiology, Faculty of Medicine, Taif University, Taif 21974, Saudi Arabia; \\ ${ }^{2}$ Department of Physiology, Faculty of Veterinary Medicine, Kafrelsheikh University, Kafrelsheikh 33516, Egypt
}

Received March 4, 2015; Accepted July 3, 2015

DOI: $10.3892 /$ etm.2015.2719

\begin{abstract}
Bile acids are considered to promote carcinogenesis. Cytochrome P450 1A1 (CYP1A1) plays a critical role in the biotransformation of drugs and procarcinogens. This study aimed to investigate the ability of bile acids to modulate CYP1A1 expression. Treatment of HepG2 cells with chenodeoxycholic acid (CDCA) and Sudan III (S.III) upregulated CYP1A1 transcriptional activity in HepG2 cells and CYP1A1 mRNA expression in H4IIE cells. Pretreatment of the HepG2 and H4IIE cells with CDCA upregulated the S.III-induced CYP1A transcriptional activity and mRNA expression. The CDCA-induced enhancement of CYP1A1 was not abolished by the p38 inhibitor SB203580. However, exposure of the cells to the mitogen-activated protein kinase kinase (MEK)1/2 inhibitor PD98059 suppressed the CDCA-induced enhancement of CYP1A1. These results show the ability of CDCA to upregulate CYP1A1 transcription and expression, which may explain the hepatocarcinogenesis-inducing effect of cholestasis. The CDCA-induced upregulation of CYP1A1 most probably proceeded through MEK1/2 activation, indicating that this may be a therapeutic target to prevent the cancer-promoting effects of excessive amounts of bile acids.
\end{abstract}

Correspondence to: Dr Zein Shaban Ibrahim, Department of Physiology, Faculty of Medicine, Taif University, 94 King Saud Street, Taif 21974, Saudi Arabia

E-mail: zainibrahim2012@yahoo.com

Abbreviations: ROS, reactive oxygen species; CYP1A1, cytochrome P450 1A1; PAHs, polycyclic aromatic hydrocarbons; HAAs, heterocyclic aromatic amines/amides; AhR, aryl hydrocarbon receptor; CDCA, chenodeoxycholic acid; XRE, xenobiotic response element; DMSO, dimethylsulfoxide; HepG2, human hepatoma cells; XRE, xenobiotic response element; H4IIE, rat hepatoma cells; MAPK, mitogen-activated protein kinase; MEK, mitogen-activated protein kinase kinase; p38, p38 mitogen-activated protein kinase; $\mathrm{XAP} 2$, hepatitis $\mathrm{B}$ virus $\mathrm{X}$ protein associated protein 2

Key words: CDCA, CYP1A1, H4IIE cells, HepG2 cells

\section{Introduction}

Bile acids have been implicated as causative agents in cancers of the gastrointestinal tract, including cancers of the stomach (1), small intestine (2), biliary tract (3) and colon (4). Bile acids themselves cannot induce tumors (5); however, their presence or absence in the colon has been demonstrated to be a strong determinant of tumor incidence (6). Bile acids are considered to lack the ability to initiate tumorigenesis mainly on the basis that they are unable to induce DNA damage directly; therefore, bile acids are hypothesized to promote colon tumorigenesis by affecting intracellular signaling (7). Cholestasis is reported to cause the intra-hepatic retention of potentially toxic bile acids, which causes liver injury and biliary fibrosis or cirrhosis (8). This has been observed in rats with sustained high levels of bile acids following the intravenous infusion of bile acids (9) and in bile duct-ligated rats (10). Oxidative stress induces DNA damage, which causes chromosomal aberrations associated with cell transformation (11). Since bile acids induce oxidative stress, they are thus considered potential carcinogens (12).

Cytochrome P450 (CYP) constitutes a superfamily of heme-containing enzymes that take part in the metabolism and elimination of various exogenous and endogenous substances $(13,14)$. They play critical roles in the biotransformation of drugs, carcinogens, steroid hormones and environmental toxicants (15-17). CYP1A1 and CYP1A2 catalyze the oxygenation of polycyclic aromatic hydrocarbons (PAHs) and heterocyclic aromatic amines/amides (HAAs) (18). Changes in the levels of CYPs may contribute to the development of cancer (13). PAHs induce CYP1A via the aryl hydrocarbon receptor (AhR), a ligand-activated transcription factor. When PAHs bind to AhR, sequential signaling events are initiated that activate the AhR and induce transcription of CYP1A genes through the xenobiotic response element (XRE) located in the enhancers of the genes (19).

Humans are exposed to PAHs and HAAs from a wide range of sources, including tobacco smoke, automobile exhaust, smoked and cooked food and industrial processes. Such exposure has been causatively linked to an increased incidence of cancers in smokers and certain other populations (20). One of the most well-characterized molecular responses to PAHs is the induction of the CYP1A1 gene, which encodes the carcinogen-activating enzyme CYP1A1 (21). Moreover, chemicals present in the diet can activate AhRs; several dietary 
plant compounds have been reported to competitively bind to and/or induce AhR-dependent gene expression. These include 7,8-dehydrorutacarpine (22), indole-[3,2-b]-carbazole (ICZ) derivatives (23), curcumin (24) and certain carotinoids (25). Furthermore, dietary indoles including indole 3-carbinol (I3C) and tryptophan can be converted in the mammalian digestive tract into more potent AhR ligands. ICZ, an acidic condensation product of I3C, the most potent natural AhR ligand (23), has been detected in rat feces (26). Certain flavanoids have also been reported to be AhR ligands, such as quercetin (27) and tangeritin (28). The metabolic activation of PAHs and HAAs by CYP1A enzymes is a critical step in the development of cancer in human populations exposed to PAHs and HAAs (19). CYP1A1/2 enzymes are highly inducible by a range of chemicals (29). Their modulation may occur through pre- or post-transcriptional or pre-translational mechanisms.

A marked activation of CYP1A1 and CYP1A2 genes has been observed in congenitally jaundiced Gunn rats (30). Despite numerous studies on the association between bile acids and carcinogenesis, to the best of our knowledge, the effects of bile acids on CYP1A have not been fully elucidated. This prompted the investigation of the effects of bile acids on CYP1A1 induction using one of the most abundant primary bile acids, chenodeoxycholic acid (CDCA), in the present study. The effects on CYP1A1 transcription pre- or post-transcription and protein expression were examined, and the possible signaling pathways involved in the modulating effects of bile acids on CYP1A1 expression were elucidated.

\section{Materials and methods}

Materials. Fetal bovine serum (FBS), chenodeoxycholic acid (CDCA) and Sudan III (S.III) were obtained from Sigma-Aldrich (St. Louis, MO, USA). Polyclonal goat anti-rat CYP1A1 (\#299124) was acquired from Daiichi Pure Chemicals Co., Ltd. (Tokyo, Japan), horseradish peroxidase-labeled rabbit anti-goat IgG (\#A8919) was obtained from Sigma-Aldrich, and polyclonal goat anti-rat $\beta$-actin (\#sc-130657) was from Santa Cruz Biotechnology (Dallas, TX, USA). Human hepatoma (HepG2) cells were obtained from the American Type Culture Collection (Manassas, VA, USA). Rat hepatoma (H4IIE) cells were obtained from the American Type Culture Collection (Rockville, MD, USA). PD98059, a mitogen-activated protein kinase kinase (MEK) inhibitor, was from Biomol Research Laboratories, Inc. (Plymouth, PA, USA) and SB203580, a p38 inhibitor, was from Sigma-Aldrich. Other chemicals were of analytical grade.

Luciferase activity assay of HepG2 cells. HepG2 cells were grown in Dulbecco's modified Eagle's medium (DMEM) supplemented with $10 \% \mathrm{FBS}$, and antibiotics $(100 \mathrm{U} / \mathrm{ml}$ penicillin and $100 \mu \mathrm{g} / \mathrm{ml}$ streptomycin) at $37^{\circ} \mathrm{C}$ in a humidified atmosphere of $5 \% \mathrm{CO}_{2}$ in air. Cells were seeded at $70 \%$ confluence on 96-well collagen-coated plates. After $24 \mathrm{~h}$, cells were transfected with $50 \mathrm{ng} /$ well pGL3-XRE and 5 ng/well pRL-SV40 vector (Promega KK, Tokyo, Japan) using TransIt-pGL3-Transfection Reagent (Mirus Bio LLC, Madison, WI, USA) according to the manufacturer's instructions for $12 \mathrm{~h}$, after which the medium was replaced by new medium containing dimethylsulfoxide (DMSO; control), $0.25 \mu \mathrm{M}$ S.III and/or 60, 90 or $120 \mu \mathrm{M}$ CDCA for $24 \mathrm{~h}$. Cells were lysed and firefly and Renilla luciferase activities were measured from six independent transfections using the Dual-Luciferase ${ }^{\circledR}$ Reporter assay system (Promega Corporation, Madison, WI, USA). Transfection data are expressed as fold induction of firefly to Renilla luciferase activities relative to empty vector or vehicle control. The experiment was repeated three times

Treatment of H4IIE cells. Rat H4IIE cells were grown in DMEM supplemented with $10 \% \mathrm{FBS}$, and antibiotics (100 IU/ml penicillin and $100 \mu \mathrm{g} / \mathrm{ml}$ streptomycin) at $37^{\circ} \mathrm{C}$ in a humidified atmosphere of $5 \% \mathrm{CO}_{2}$ in air. Cells were seeded in 60-mm collagen-coated dishes and sub-cultured twice a week. H4IIE cells were grown to the confluent stage, after which they were treated with $0.1 \%$ DMSO (control), $0.25 \mu \mathrm{M} \mathrm{S.III} \mathrm{and/or}$ CDCA at concentrations of 60,90 or $120 \mu \mathrm{M}$ for a further $24 \mathrm{~h}$, after which cells were harvested for RNA extraction.

In another experiment, H4IIE cells were grown to the confluent stage, as described above. They were then treated with $10 \mu \mathrm{M}$ PD98059 or SB203580 for $40 \mathrm{~min}$ prior to the application of $0.1 \%$ DMSO (control), $0.25 \mu \mathrm{M} \mathrm{S}$.III and/or $90 \mu \mathrm{M}$ CDCA for a further $24 \mathrm{~h}$. The cells were then harvested for protein analysis.

RNA extraction. Total RNA was isolated from the H4IIE cell cultures using TRIzol reagent (Life Technologies Inc., Grand Island, NY, USA). Briefly cell cultures from the $60-\mathrm{mm}$ dishes were homogenized in $1 \mathrm{ml}$ TRIzol reagent. Then, $0.3 \mathrm{ml}$ chloroform was added to the sample. The mixtures were shaken for $30 \mathrm{sec}$ followed by centrifugation at $4^{\circ} \mathrm{C}$ and $12,500 \mathrm{x} \mathrm{g}$ for $20 \mathrm{~min}$. The supernatant layers were transferred to a new set of tubes, an equal volume of isopropanol was added and the samples were shaken for $15 \mathrm{sec}$ and centrifuged $4^{\circ} \mathrm{C}$ and $12,500 \mathrm{x} \mathrm{g}$ for $15 \mathrm{~min}$. The RNA pellets were washed with $70 \%$ ethanol. RNA was dissolved in diethylpyrocarbonate (DEPC)-treated water and the prepared RNA was examined by electrophoresis, which showed that the RNA integrity was acceptable. The RNA was further checked by measurement of its optical density using a Nanodrop ND-1000 spectrophotometer (Thermo Fisher Scientific, Waltham, MA, USA). The ratio of sample absorbance at 260 and $280 \mathrm{~nm}$ for all RNA samples was 1.7-1.9.

Reverse transcription-polymerase chain reaction (RT-PCR). A mixture of $5 \mu \mathrm{g}$ total RNA and $0.5 \mathrm{ng}$ oligo(dT) primer in a total volume of $24 \mu \mathrm{l}$ sterilized ultra-pure water, was incubated at $70^{\circ} \mathrm{C}$ for $10 \mathrm{~min}$ and then made up to $40 \mu \mathrm{l}$ with a mixture of $8 \mu 1$ 5X RT-buffer, $2 \mu 110 \mathrm{mM}$ dNTP, $2 \mu 1$ DEPC water and $2 \mu 1$ of reverse transcriptase (Toyobo Co., Ltd., Osaka, Japan). The resultant mixture was incubated in the thermal cycler (Bio-Rad Laboratories, Inc., Hercules, CA, USA) at $30^{\circ} \mathrm{C}$ for $10 \mathrm{~min}$, $42^{\circ} \mathrm{C}$ for $1 \mathrm{~h}$ and $90^{\circ} \mathrm{C}$ for $10 \mathrm{~min}$. For PCR, $1 \mu \mathrm{l}$ aliquots of the synthesized cDNA were added to $19 \mu \mathrm{l}$ of a mixture containing sterilized ultra-pure water, $2 \mu \mathrm{l}$ 10X PCR buffer, $2 \mu \mathrm{l}$ dNTP (2.5 mM), $0.3 \mu \mathrm{l} 10 \mu \mathrm{M}$ sense and anti-sense primers and $0.1 \mu \mathrm{l}$ Taq polymerase (Takara, Kyoto, Japan). The primers were as follows: CYP1A1 sense, CCATGACCAGGAACTATGGG and anti-sense, TCTGGTGAGCATCCAGGACA [GenBank accession no., X00469; Parkin (31)]; $\beta$-actin sense, ATGTACGTAGCCATCCAGGC and anti-sense, 
TCCACACAGAGTACTTGCGC (GenBank accession no., V01217). Amplification was initiated by 1 cycle of denaturation at $94^{\circ} \mathrm{C}$ for $4 \mathrm{~min}$, followed by a 24 cycles, each comprising denaturation at $94^{\circ} \mathrm{C}$ for $1 \mathrm{~min}$, annealing at $56^{\circ} \mathrm{C}$ for $1 \mathrm{~min}$ and extension at $72^{\circ} \mathrm{C}$ for $1 \mathrm{~min}$. After the last cycle of amplification, samples were finally incubated for $7 \mathrm{~min}$ at $72^{\circ} \mathrm{C}$. Amplified PCR products were separated by electrophoresis through $1.5 \%$ agarose gel. The product size of CYP1A1 was $341 \mathrm{bp}$ and that of $\beta$-actin was $628 \mathrm{bp}$. Bands were stained with ethidium bromide and visualized by ultraviolet illumination. Photographic images were converted into computer files with an Epson color-image scanner (Suwa, Japan) in combination with Adobe Photoshop 6.0 software (Adobe Systems, San Jose, CA, USA).

Western blot analysis. Following the experimental treatments, H4IIE cells were washed with ice-cold phosphate-buffered saline (PBS) and scraped in ice-cold lysis buffer [50 mM HEPES ( $\mathrm{pH}$ 7.5), $150 \mathrm{mM} \mathrm{NaCl}, 5 \mathrm{mM}$ EDTA, $20 \mathrm{mM}$ sodium fluoride, $10 \mathrm{mM}$ sodium pyrophosphate, $2 \mathrm{mM}$ sodium vanadate, $1 \%$ Nonidet P-40 and complete protease inhibitor cocktail]. Harvested cells were incubated on ice for $30 \mathrm{~min}$ followed by centrifugation at $12,000 \mathrm{x}$ g for $20 \mathrm{~min}$ at $4^{\circ} \mathrm{C}$ to obtain cell lysates. Portions of the cell lysate ( $40 \mu \mathrm{g}$ cell lysate supernatant), were resolved by $10-12 \%$ SDS-PAGE electrophoresis. The proteins were transferred electrophoretically to nitrocellulose membranes, and blocked with $5 \%$ skimmed milk in PBS containing 1\% Tween 20 for $2 \mathrm{~h}$ at room temperature. The membranes were stained with Ponceau $\mathrm{S}$ to confirm transfer and to ensure equal protein loading for each sample. The membranes were blocked in 5\% skimmed milk in PBS with $1 \%$ Tween 20 for $2 \mathrm{~h}$ at room temperature followed by incubation with goat anti-rat CYP1A1 and $\beta$-actin primary antibodies (1:100 dilution) at room temperature for $3 \mathrm{~h}$ and then exposed to horseradish peroxidase-conjugated rabbit anti-goat secondary antibodies (1:200 dilution in PBS) for $3 \mathrm{~h}$ at room temperature. Immunoreactive protein bands were detected with the ECL-Plus chemiluminescence kit (Amersham Life Science, Cleveland, OH, USA). Intensities of the immunoreactive bands were analyzed densitometrically using public domain NIH Image software (http://rsb.info.nih gov/nih-image/). CYP1A1 protein bands were normalized against the respective band intensity of $\beta$-actin and normalized to control levels.

Statistical analysis. All data are expressed as means \pm standard deviations. Statistical significances were evaluated using the Tukey-Kramer honest significant difference test with JMP software (SAS Institute, Cary, NC, USA). Results were considered to be statistically significant when $\mathrm{P}<0.05$.

\section{Results}

CDCA upregulates S.III-induced CYPIAl transcriptional activity. The effect of CDCA on CYP1A1 mRNA could potentially be pre-transcriptional, transcriptional or post-transcriptional. To confirm the exact level at which CDCA modulates CYP1A1 induction, CYP1A1 promoter activity was investigated by XRE-luciferase reporter assays in HepG2 cells. Reporter activity was induced by $0.25 \mu \mathrm{M} \mathrm{S}$.III to a level

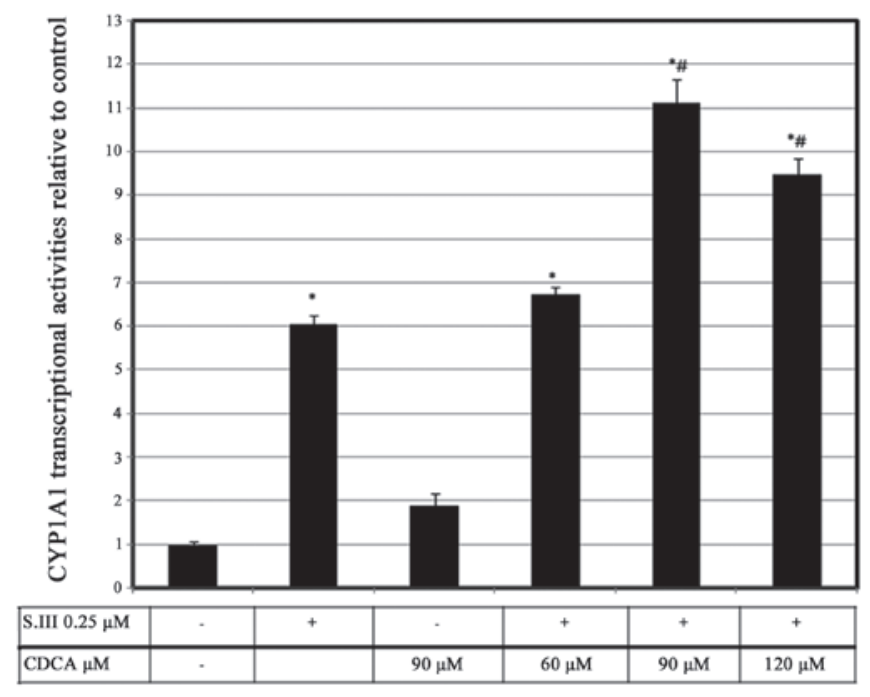

Figure 1. Upregulation of Sudan III (S.III)-induced cytochrome P450 1A1 (CYP1A1) transcriptional activity by chenodeoxycholic acid (CDCA) HepG2 cells in 96-well plates were transiently transfected with the CYP1A15-flanking reporter plasmid pGL3-XRE, together with the pRL-TK control plasmid in serum-free medium. Twelve hours later the medium was changed and the cells were treated for $24 \mathrm{~h}$ with dimethylsulfoxide (DMSO), or $0.25 \mu \mathrm{M}$ S.III with or without different concentrations of CDCA with 6 separate wells for each. The cells were then harvested and luciferase activities were measured. Data are the means \pm standard deviations of three experiments. ${ }^{*} \mathrm{P}<0.05$ vs. the DMSO control. ${ }^{\#} \mathrm{P}<0.05$ vs. S.III alone.

of $\sim 6$-fold higher than that of the control. However, $90 \mu \mathrm{M}$ CDCA induced luciferase activity to only 1.8 -fold more than the control levels. Treatment of the cells with $60 \mu \mathrm{M}$ CDCA plus $0.25 \mu \mathrm{M}$ S.III slightly increased CYP1A1 transcriptional activity. However, treatment of the cells with $90 \mu \mathrm{M}$ CDCA plus $0.25 \mu \mathrm{M}$ S.III induced CYP1A1 transcriptional activity to a level 11-fold greater than the control. Treatment of the HepG2 cells with $120 \mu \mathrm{M}$ CDCA plus $0.25 \mu \mathrm{M}$ S.III did not cause a further increase of the CYP1A1 transcriptional activity (Fig. 1)

CDCA upregulates S.III-induced CYPIA1 mRNA expression. To further elucidate the effect of CDCA on CYP1A1 transcription, rat H4IIE cells were treated with different concentrations of CDCA in addition to $0.25 \mu \mathrm{M}$ of the CYP1A1 inducer S.III, and the effect of this combination on CYP1A1 mRNA expression was evaluated. Treatment of H4IIE cells with $0.25 \mu \mathrm{M}$ S.III plus increasing doses of CDCA caused upregulation of the S.III-induced CYP1A1 mRNA in CDCA-dose-dependent manner (Fig. 2).

Effect of pre-exposure to CDCA on CYPIAl transcriptional activity and $m R N A$ expression. To further determine the exact level of the effect of CDCA on CYP1A1 transcription, HepG2 cells were treated with different doses of CDCA for $8 \mathrm{~h}$ prior to treatment with $0.25 \mu \mathrm{M} \mathrm{S}$.III. The CYP1A1 reporter assay was then conducted. Pre-exposure of HepG2 cells to different concentrations of CDCA prior to $0.25 \mu \mathrm{M}$ S.III resulted in upregulation of the S.III-induced transcriptional activity of CYP1A1 in a CDAC-dose-dependent manner, with the greatest inductive effect at $90 \mu \mathrm{M} \mathrm{CDCA}$ (Fig. 3). To further confirm the predisposing effect of CDCA on the induction of CYP1A1 by S.III, H4IIE cells were pre-exposed to CDCA $90 \mu \mathrm{M}$ for 

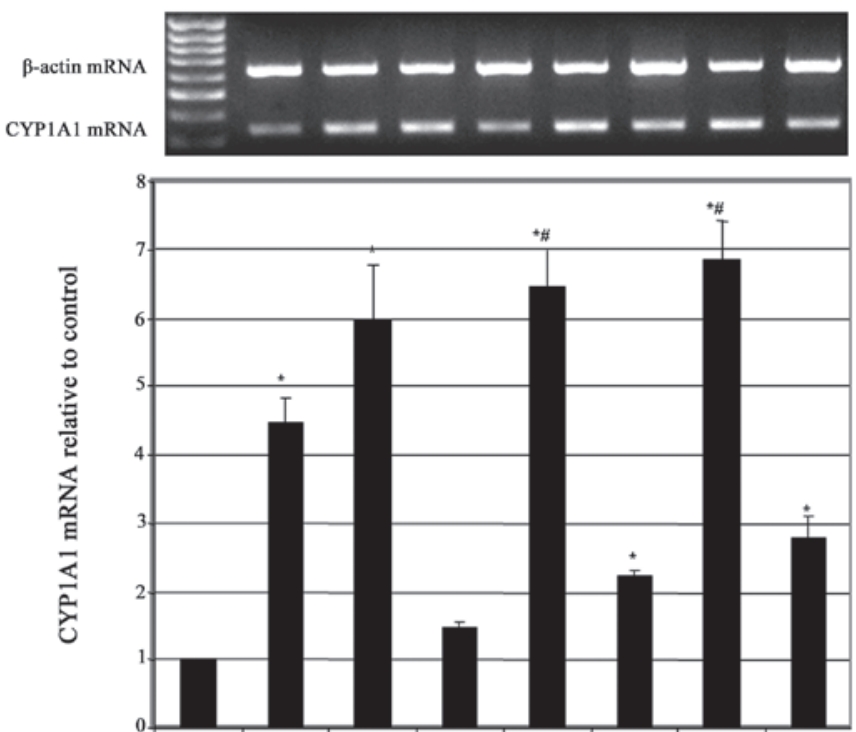

\begin{tabular}{|c|c|c|c|c|c|c|c|c|}
\hline S.III $0.25 \mu \mathrm{M}$ & $\cdot$ & + & + & $\cdot$ & + & $\cdot$ & + & $\cdot$ \\
\hline $\mathrm{CDCA} \mu \mathrm{M}$ & $\cdot$ & $\cdot$ & 60 & 60 & 90 & 90 & 120 & 120 \\
\hline
\end{tabular}

Figure 2. Upregulation of Sudan III (S.III)-induced cytochrome P450 1A1 (CYP1A1) mRNA by chenodeoxycholic acid (CDCA). Semi-quantitative reverse transcription-polymerase chain reaction analysis of CYP1A1 mRNA. H4IIE cells seeded on 60-mm dishes were treated with S.III with or without different concentration of CDCA. The cDNA samples were amplified as described in Materials and methods. The densitometry of the bands of CYP1A1 mRNA were normalized to the corresponding bands $\beta$-actin and presented relative to control. The data are the means \pm standard deviations of three experiments with three different dishes in each experiment. ${ }^{*} \mathrm{P}<0.05$ compared with the control; ${ }^{* \#} \mathrm{P}<.005$ compared with the S.III-induced level.

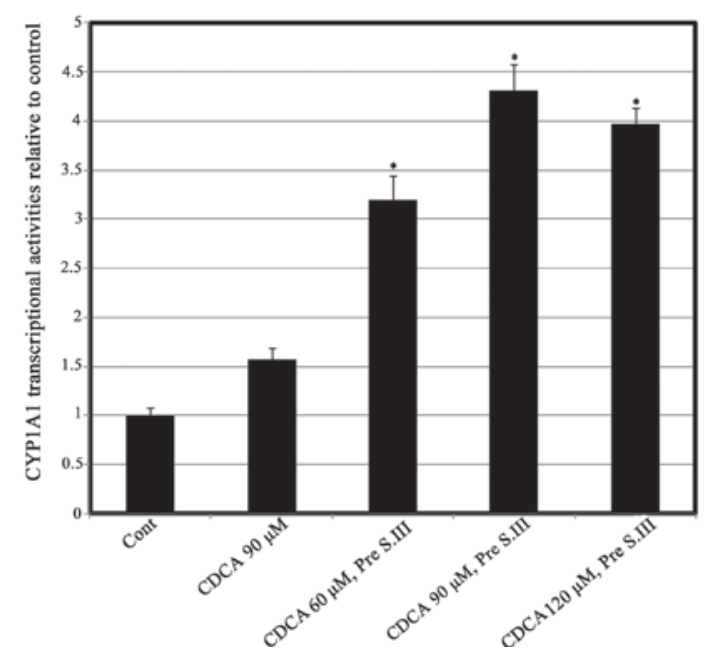

Figure 3. Effect of pre-exposure of HepG2 cells to chenodeoxycholic acid (CDCA) on the transcriptional activity of cytochrome P450 1A1 (CYP1A1). HepG2 cells were transiently transfected with the CYP1A1 5-flanking reporter plasmid, pGL3-XRE, together with the pRL-TK control plasmid in serum-free medium. Twelve hours later the medium was changed and the cells were treated with different concentration of CDCA for $8 \mathrm{~h}$, after which cells were treated with dimethylsulfoxide (DMSO), or $0.25 \mu \mathrm{M}$ Sudan III (S.III). Six separate wells were used for each experiment. Luciferase activities were measured in the harvested cells. Data are the means \pm standard deviations of three experiments. ${ }^{*} \mathrm{P}<0.05$ ) compared with DMSO control (Cont).

different exposure times prior to treatment with $0.25 \mu \mathrm{M}$ S.III and CYP1A1 mRNA expression was measured. As shown in (Fig. 4), pre-exposure to $90 \mu \mathrm{M}$ CDCA for between 1
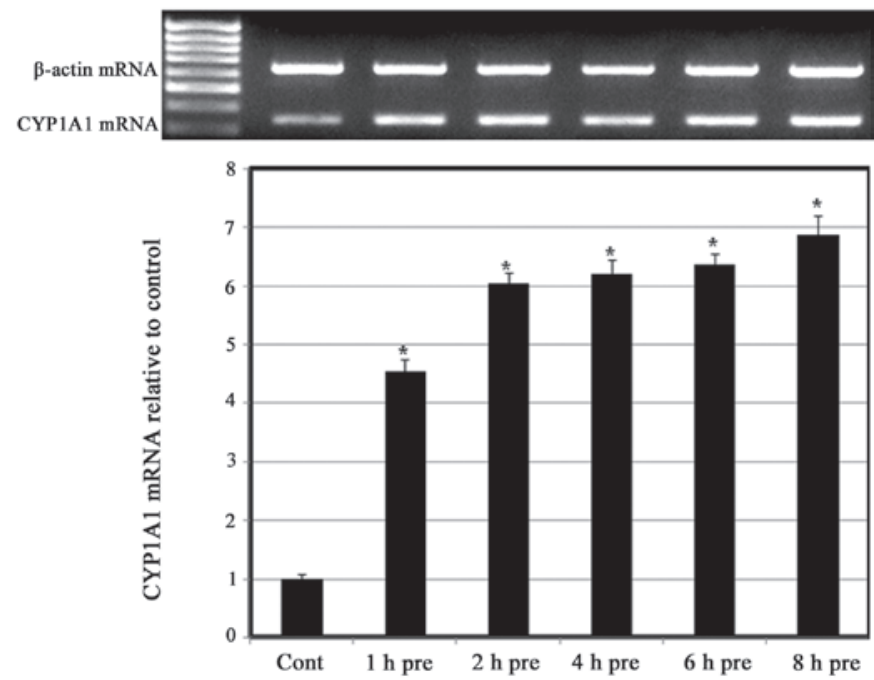

Figure 4. Effect of pre-exposure of H4IIE cells to chenodeoxycholic acid (CDCA) on the expression of cytochrome P450 1A1 (CYP1A1) mRNA. H4IIE cells were seeded on 60-mm dishes. After reaching $95-100 \%$ confluent, cells were treated with $90 \mu \mathrm{M} \mathrm{CDCA}$ for different times prior to treatment with $0.25 \mu \mathrm{M}$ Sudan III (S.III). Cells were harvested with TRIzol for RNA extraction and reverse transcription-polymerase chain reaction. The cDNA samples were amplified as described in Materials and methods. The densitometry of the bands of CYP1A1 mRNA were normalized to the corresponding bands for $\beta$-actin and presented relative to control (Cont). The data are the means \pm standard deviation of three experiments with three different dishes in each experiment. "P $<0.05$ compared with Cont.

and $8 \mathrm{~h}$ upregulated the expression of CYP1A1 mRNA in a time-dependent manner.

Role of p38 in the CDCA-induced upregulation of CYP1A1 $m R N A$ expression. Whether p38 is involved in the enhancing effect of CDCA on CYP1A1 induction by S.III was investigated. H4IIE cells were treated with the p38 inhibitor SB203580 alone or in combination with $90 \mu \mathrm{M}$ CDCA or $0.25 \mu \mathrm{M}$ S.III, and CYP1A1 protein expression levels were measured by western blotting. Treatment of the cells with CDCA in combination with S.III induced a 5-fold increase in CYP1A1 protein levels compared with the control, and the levels were higher than those induced by S.III alone. Treatment with SB203580 alone induced CYP1A1 protein expression to 2-fold the control levels. When combined with S.III, SB treatment caused a 10 -fold induction of CYP1A 1 protein expression levels compared with only 4 -fold induction by S.III alone. When combined with CDCA, SB treatment caused a 7-fold induction of CYP1A1 protein expression compared with only 1.2-fold induction by CDCA alone (Fig. 5).

Role of MEK1/2 in the CDCA-induced upregulation of CYP1A1 protein expression. Whether mitogen-activated protein kinase (MAPK) is involved in the enhancing effect of CDCA on CYP1A1 induction by S.III was investigated. H4IIE cells were treated with the MAPK inhibitor PD98059 alone or in combination with $90 \mu \mathrm{M}$ CDCA and/or $0.25 \mu \mathrm{M}$ S.III and CYP1A1 protein expression levels were measured by western blotting. Treatment of H4IIE cells with PD98059 alone did not affect the basal CYP1A1 protein expression; however, when PD98059 was combined with CDCA, a reduction of the CDCA-induced CYP1A1 protein levels (Fig. 6, bar 9) to 

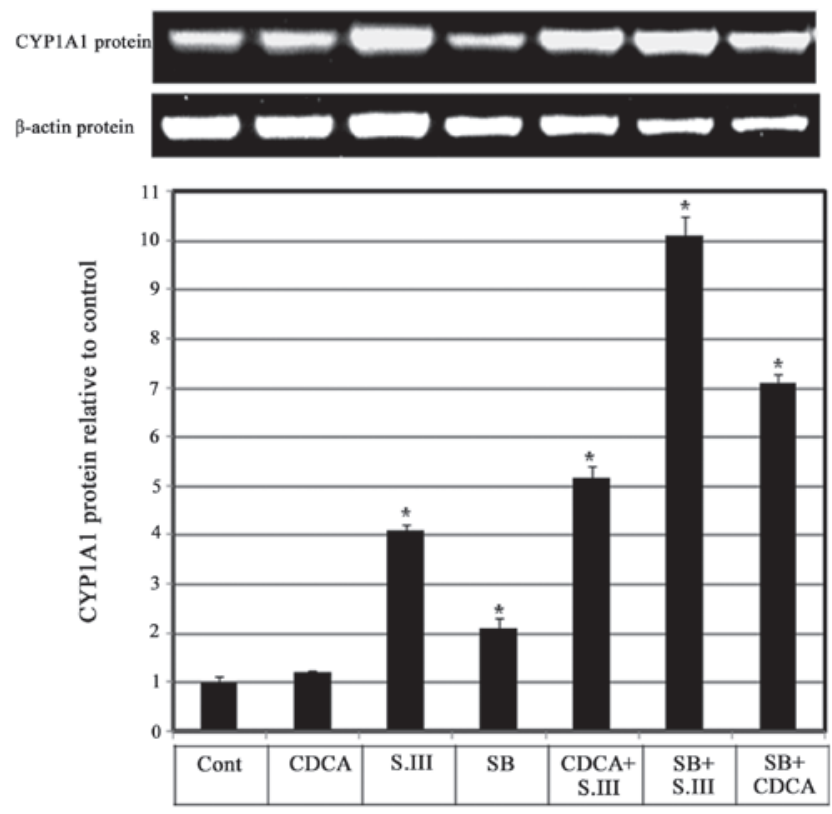

Figure 5. Role of p38 in the chenodeoxycholic acid (CDCA)-induced upregulation of cytochrome P450 1A1 (CYP1A1) protein expression. H4IIE cells seeded in $60-\mathrm{mm}$ dishes were treated for $40 \mathrm{~min}$ with $10 \mu \mathrm{M} \mathrm{SB} 203580$ (SB) or not, before the application of $0.1 \%$ dimethylsulfoxide (control, Cont), $0.25 \mu \mathrm{M}$ Sudan III (S.III) and/or $90 \mu \mathrm{M}$ CDCA for a further $24 \mathrm{~h}$. Protein expression levels were analyzed by western blotting as described in Materials and methods. Densitometric data of the CYP1A1 bands were normalized to the corresponding bands of $\beta$-actin and presented relative to control. The data are the means \pm standard deviations of three experiments with three different dishes in each experiment. ${ }^{*} \mathrm{P}<0.05$ vs. control.

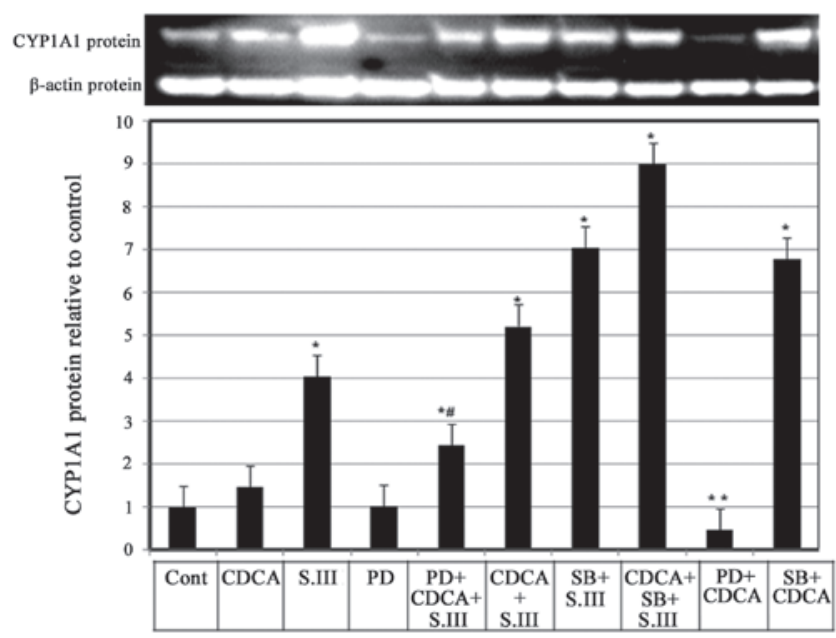

Figure 6. Role of mitogen-activated protein kinase kinase (MEK)1/2 in the promoting effect of chenodeoxycholic acid (CDCA) on Sudan III (S.III)-induced cytochrome P450 1A1 (CYP1A1) protein expression. H4IIE cells seeded in $60-\mathrm{mm}$ dishes were treated with $10 \mu \mathrm{M} \mathrm{SB} 203580$ (SB) or PD98059 (PD) for $40 \mathrm{~min}$ prior to the application of $0.1 \%$ dimethylsulfoxide, $0.25 \mu \mathrm{M}$ S.III and/or $90 \mu \mathrm{M}$ CDCA for a further $24 \mathrm{~h}$. Protein expression levels were analyzed by western blotting as described in Materials and methods. Densitometric data of the CYP1A1 mRNA bands were normalized to the corresponding bands of $\beta$-actin and presented relative to control. Data are the means \pm standard deviations of three experiments with three different dishes in each experiment. ${ }^{*} \mathrm{P}<0.05$ vs. control; ${ }^{* *} \mathrm{P}<0.05$ vs. CDCA + S.III; ${ }^{* *} \mathrm{P}<0.05$ vs. CDCA alone.

only 25\% of the levels induced by CDCA alone (Fig. 6, bar 2). When PD98059 was combined with CDCA and $0.25 \mu \mathrm{M}$
S.III, CYP1A1 protein expression levels were 2.3 -fold greater than control levels, which was lover than the 5.2-fold increase obtained with CDCA combined with $0.25 \mu$ M S.III (Fig. 6, bars 5 and 6). In order to compare the effects of MEK1/2 inhibitor PD98059 and p38 inhibitor SB203580, H4IIE cells with were treated with SB203580 and S.III $0.25 \mu \mathrm{M}$ (Fig. 6, column 7) and SB203580 combined with S.III and CDCA (Fig. 6, column 8) or in combination with CDCA only (Fig. 6, column 10). The results demonstrate that the p38 inhibitor SB203580 upregulates the induction of CYP1A1 protein by CDCA and/or S.III.

\section{Discussion}

The present study has demonstrated the ability of the bile acid CDCA to upregulate the induction of CYP1A1 in response to an inducer, a mechanism through which bile acids could promote liver carcinogenesis. Liver cancer is one of the most common forms of cancers worldwide, and both genetic and environmental factors contribute to hepatocarcinogenesis (32). Cholestasis is associated with the hepatic and systemic accumulation of toxic biliary compounds, such as bile acids and bilirubin, and subsequent liver damage (33). Bile acids have been shown to promote liver tumors in a hepatitis B virus transgenic mouse model (34). The carcinogen-activating enzyme CYP1A1 (22) is a key participant in the bioactivation of numerous procarcinogenic substances such as carcinogenic polycyclic hydrocarbons and aromatic amines (35). S.III has been reported to increase the expression levels of human CYP1A1 mRNA in HepG2 cells (36). The S.III-induced CYP1A1 transcription in HepG2 cells (Fig. 1) and mRNA expression in H4IIE cells (Fig. 2) were enhanced by the concurrent administration of CDCA, which indicates a promoting effect of CDCA on CYP1A1 induction in the liver.

An association between an increased concentration of bile acids and carcinogenesis has been reported to be associated with a marked activation of CYP1A1 and CYP1A2 genes in congenitally jaundiced Gunn rats (30). However, the mechanism of that association has not been elucidated. In the present study, the upregulation of S.III-induced CYP1A1 transcription in HepG2 cells (Fig. 3) and S.III-induced CYP1A1 mRNA expression in H4IIE cells (Fig. 4) following pre-exposure to CDCA indicates the ability of CDCA to sensitize the cells to the inductive effect of S.III on CYP1A1. Modulation of CYP enzymes occurs through pre-transcriptional, post-transcriptional or pretranslational mechanisms. Mercury has been demonstrated to downregulate the expression of CYP1A1 at the transcriptional and posttranslational levels in HepG2 cells (37). In the present study, the upregulation of S.III-induced CYP1A1 transcription and mRNA due to CDCA pre-exposure indicates that CDCA modulates CYP1A1 at the pre-transcriptional level. This implies that CDCA sensitizes the cells in some way so that their response to CYP1A1 inducers is increased. Indeed, it has been demonstrated that the bile acid-mediated induction of adhesion molecule expression occurs by stimulation of NF- $\mathrm{\kappa B}$ and p38 MAPK signaling pathways through an elevation of reactive oxygen species (38). Therefore, H4IIE cells were exposed to a selective inhibitor of $\mathrm{p} 38$ MAPK in the present 
study. SB203580 has been reported to suppress induction of the CYP1A1 gene by 2,3,7,8-tetrachlorodibenzo- $p$-dioxin (TCDD) through a p38 MAPK-independent pathway in HepG2 human hepatoma cells (39). Pre-exposure of the H4IIE cells to SB203580 did not suppress the induction of CYP1A1 protein by CDCA or S.III, instead it upregulated CYP1A1 expression (Fig. 5), indicating the enhancement of CYP1A1 induction by CDCA did not occur through the p38 MAPK pathway. Moreover, SB203580 application alone induced CYP1A1 protein expression to increase to double the control level. This ability of SB203580 to induce CYP1A1 expression is in accordance with the previously reported ability of SB203580 to directly bind and activate AhR, and induce CYP1A1 gene expression in an AhR-dependent manner in human HepG2 cells and Hepa 1c1c7 cells (40). Previously the bile acids deoxycholic and chenodeoxycholic acid have been shown to activate ERK-MEK in mouse hepatocytes (41). Therefore, this mechanism was further tested using the potent MEK inhibitor PD98059 (42). The ability of PD98059 to suppress the CDCA-induced expression of CYP1A1 and the CDCA-promoted S.III-induced expression of CYP1A1 (Fig. 6), indicates that CDCA may promote CYP1A1 induction through sensitizing the cells by the modulation of cell signaling, mainly through the upregulation of MEK1/2.

PAHs induce CYP1A via the AhR. When PAHs bind to the AhR, they activate the transcription of CYP1A genes through the dioxin-response element located in the enhancers of the genes (20). The AhR is an intracellular mediator of the xenobiotic signaling pathway and is complexed with HSP90 (43) and hepatitis B virus X protein associated protein 2 (XAP2) (44) in the cytoplasm. Xenobiotics such as TCDD and 3-methylcholanthrene (3MC) bind to the AhR with an extremely high affinity, and the receptor complex subsequently translocates to the nucleus, where it switches its partner molecule from HSP90 to the AhR nuclear translocater (Arnt) protein) (44). In the nucleus, the formed AhR/Arnt heterodimer binds to the XRE sequences, which are enhancer DNA elements present in the 5-flanking region of target genes CYP1A1/1A2, in addition to genes for a series of xenobiotic-metabolizing enzymes, cell cycle and growth-related factors (19). The ability of S.III to induce CYP1A1 in rat liver has previously been demonstrated (45). Sudan dyes possess a high affinity for AhRs at the same cavity as other well-known AhR ligands, such as dioxins and 3-MC (46). S.III, an AhR ligand, has the ability to stimulate AhR nuclear translocation and binding to the XRE in the promoter region of CYP1A1 and induce its transcription (36). The ability of CDCA to enhance CYP1A1 transcription and expression could be the key mechanism underlying the reported effect of bile acids on the promotion of liver tumors in a hepatitis B virus transgenic mouse model (34).

CYP1A is known to cause the metabolic activation of promutagens and procarcinogens (47). The enhancing effect of CDCA on the induction of CYP1A1 by S.III may underlie cholestasis-associated hepatic liver damage (34).

This study demonstrated the ability of CDCA to enhance AhR ligand-induced CYP1A1 expression, which may explain the hepatocarcinogenesis-prompting effect of cholestasis. It also suggests that the CDCA-induced upregulation of CYP1A1 proceeds through the CDCA-activated MEK1/2 pathway.
Therefore, this pathway that may be a therapeutic target for the prevention of the promoting effect of CDCA on pro-carcinogenic activation.

\section{Acknowledgements}

The author would like to thank Professors Shoichi Fujita and Mayumi Ishizuka of the Laboratory of Toxicology, Department of Environmental Science, Graduate School of Veterinary Medicine, Hokkaido University (Sapporo, Japan) for their generous and continuous support. The author would like also to thank Dr Mohamed Ahmed of the Department of Biotechnology, College of Science, Taif University (Taif, Saudi Arabia) for his continuous and kind help in the completion of this study.

\section{References}

1. Kuwahara A, Saito T and Kobayashi M: Bile acids promote carcinogenesis in the remnant stomach of rats. J Cancer Res Clin Oncol 115: 423-428, 1989.

2. Ross RK, Hartnett NM, Bernstein L and Henderson BE: Epidemiology of adenocarcinomas of the small intestine: Is bile a small bowel carcinogen? Br J Cancer 63: 143-145, 1991.

3. Reveille RM, Van Stiegmann G and Everson GT: Increased secondary bile acids in a choledochal cyst. Possible role in biliary metaplasia and carcinoma. Gastroenterology 99: 525-527, 1990.

4. Bayerdörffer E, Mannes GA, Ochsenkühn T, Dirschedl P, Wiebecke B and Paumgartner G: Unconjugated secondary bile acids in the serum of patients with colorectal adenomas. Gut 36: 268-273, 1995

5. Martinez JD, Stratagoules ED, LaRue JM, Powell AA, Gause PR, Craven MT, Payne CM, Powell MB, Gerner EW and Earnest DL: Different bile acids exhibit distinct biological effects: The tumor promoter deoxycholic acid induces apoptosis and the chemopreventive agent ursodeoxycholic acid inhibits cell proliferation. Nutr Cancer 31: 111-118, 1998.

6. Morvay K, Szentléleki K, Török G, Pintér A, Börzsönyi M and Nawroth R: Effect of change of fecal bile acid excretion achieved by operative procedures on 1,2-dimethylhydrazine-induced colon cancer in rats. Dis Colon Rectum 32: 860-863, 1989.

7. Qiao D, Gaitonde SV, Qi W and Martinez JD: Deoxycholic acid suppresses $\mathrm{p} 53$ by stimulating proteasome-mediated $\mathrm{p} 53$ protein degradation. Carcinogenesis 22: 957-964, 2001.

8. Trauner M, Meier PJ and Boyer JL: Molecular pathogenesis of cholestasis. N Engl J Med 339: 1217-1227, 1998.

9. Sokol RJ, McKim JM Jr, Goff MC Jr, Ruyle SZ, Devereaux MW, Han D, Packer L and Everson G: Vitamin E reduces oxidant injury to mitochondria and the hepatotoxicity of taurochenodeoxycholic acid in the rat. Gastroenterology 114: 164-174, 1998.

10. Dueland S, Reichen J, Everson GT and Davis RA: Regulation of cholesterol and bile acid homoeostasis in bile-obstructed rats. Biochem J 280: 373-377, 1991.

11. Choi J and Ou JH: Mechanisms of liver injury. III. Oxidative stress in the pathogenesis of hepatitis C virus. Am J Physiol Gastrointest Liver Physiol 290: G847-G851, 2006.

12. Dröge W: Oxidative stress and aging. Adv Exp Med Biol 543: 191-200, 2003.

13. Chang GWM and Kam PCA: The physiological and pharmacological roles of cytochrome P450 isoenzymes. Anaesthesia 54: 42-50, 1999.

14. Renton KW: Alteration of drug biotransformation and elimination during infection and inflammation. Pharmacol Ther 92: 147-163, 2001.

15. Lu AY: The 1996 Bernard B. Brodie lecture: A journey in cytochrome P450 and drug metabolism research. Drug Metab Dispos 26: 1168-1173, 1998.

16. Conney AH: Induction of drug-metabolizing enzymes: A path to the discovery of multiple cytochromes P450. Annu Rev Pharmacol Toxicol 43: 1-30, 2003.

17. Coon MJ: Cytochrome P450: Nature's most versatile biological catalyst. Annu Rev Pharmacol Toxicol 45: 1-25, 2005.

18. Kim D and Guengerich FP: Cytochrome P450 activation of arylamines and heterocyclic amines. Annu Rev Pharmacol Toxicol 45: 27-49, 2005. 
19. Ma Q and Lu AY: CYP1A induction and human risk assessment: An evolving tale of in vitro and in vivo studies. Drug Metab Dispos 35: 1009-1016, 2007.

20. Proctor RN: Tobacco and the global lung cancer epidemic. Nat Rev Cancer 1: 82-86, 2001.

21. Whitlock JP Jr, Chichester CH, Bedgood RM, Okino ST, Ko HP, Ma Q, Dong L, Li H and Clarke-Katzenberg R: Induction of drug-metabolizing enzymes by dioxin. Drug Metab Rev 4: $1107-1127,1997$.

22. Gillner M, Bergman J, Cambillau C and Gustafsson JA: Interactions of rutaecarpine alkaloids with specific binding sites for 2,3,7,8-tetrachlorodibenzo-p-dioxin in rat liver Carcinogenesis 10: 651-654, 1989.

23. Gillner M, Bergman J, Cambillau C, Alexandersson M, Fernström B and Gustafsson JA: Interactions of indolo[3,2-b] carbazoles and related polycyclic aromatic hydrocarbons with specific binding sites for 2,3,7,8-tetrachlorodibenzo-p-dioxin in rat liver. Mol Pharmacol 44: 336-345, 1993.

24. Ciolino HP, Daschner PJ, Wang TT and Yeh GC: Effect of curcumin on the aryl hydrocarbon receptor and cytochrome P450 1A1 in MCF-7 human breast carcinoma cells. Biochem Pharmacol 56: 197-206, 1998.

25. Gradelet S,Leclerc J, Siess MH and Astorg PO: $\beta$-Apo-8-carotenal, but not $\beta$-carotene, is a strong inducer of liver cytochromes P4501A1 and 1A2 in rat. Xenobiotica 26: 909-919, 1996.

26. Perdew GH and Babbs CF: Production of Ah receptor ligands in rat fecal suspensions containing tryptophan or indole-3-carbinol. Nutr Cancer 16: 209-218, 1991.

27. Ciolino HP, Daschner PJ and Yeh GC: Dietary flavonols quercetin and kaempferol are ligands of the aryl hydrocarbon receptor that affect CYP1A1 transcription differentially. Biochem J 340: 715-722, 1999.

28. Canivenc-Lavier MC, Vernevaut MF, Totis M, Siess MH, Magdalou J and Suschetet M: Comparative effects of flavonoids and model inducers on drug-metabolizing enzymes in rat liver. Toxicology 114:19-27, .1996.

29. Whitlock JP Jr: Induction of cytochrome P4501A1. Annu Rev Pharmacol Toxicol 39: 103-125, 1999.

30. Kapitulnik $\mathrm{J}$ and Gonzalez FJ: Marked endogenous activation of the CYP1A1 and CYP1A2 genes in the congenitally jaundiced Gunn rat. Mol Pharmacol 43: 722-725, 1993.

31. Parkin DM: Global cancer statistics in the year 2000. Lancet Oncol 2: 533-543, 2001.

32. Zollner G, Marschall HU, Wagner M and Trauner M: Role of nuclear receptors in the adaptive response to bile acids and cholestasis: Pathogenetic and therapeutic considerations. Mol Pharm 3: 231-251, 2006.

33. Barone M, Maiorano E, Ladisa R, Cuomo R, Pece A, Berloco P, Caruso ML, Valentini AM, Iolascon A, Francavilla A, et al: Influence of ursodeoxycholate-enriched diet on liver tumor growth in HBV transgenic mice. Hepatology 37: 880-886, 2003.
34. Zhang CL, Zeng T, Zhao XL and Xie KQ: Garlic oil attenuated nitrosodiethylamine-induced hepatocarcinogenesis by modulating the metabolic activation and detoxification enzymes. Int J Biol Sci 9: 237-245, 2013.

35. Ohno M, Ikenaka Y and Ishizuka M: Sudan III dye strongly induces CYP1A1 mRNA expression in HepG2 cells. J Biochem Mol Toxicol 26: 16-22, 2012.

36. Amara IE, Anwar-Mohamed A and El-Kadi AO: Mercury modulates the CYP1A1 at transcriptional and posttranslational levels in human hepatoma HepG2 cells. Toxicol Lett 199: 225-233, 2010.

37. Qin P: Tang X, Elloso MM and Harnish DC: Bile acids induce adhesion molecule expression in endothelial cells through activation of reactive oxygen species, NF-kappaB, and p38. Am J Physiol Heart Circ Physiol 291: 741-747, 2006.

38. Shibazaki M, Takeuchi T, Ahmed S and Kikuchi H: Suppression by p38 MAP kinase inhibitors (pyridinyl imidazole compounds) of Ah receptor target gene activation by $2,3,7,8$-tetrachlorodibenzo-p-dioxin and the possible mechanism. J Biol Chem 279: 3869-3876, 2004

39. Korashy HM, Anwar-Mohamed A, Soshilov AA, Denison MS and El-Kadi AO: The p38 MAPK inhibitor SB203580 induces cytochrome P450 1A1 gene expression in murine and human hepatoma cell lines through ligand-dependent aryl hydrocarbon receptor activation. Chem Res Toxicol 24: 1540-1548, 2011.

40. Allen K, Kim ND, Moon JO and Copple BL: Upregulation of early growth response factor- 1 by bile acids requires mitogen-activated protein kinase signaling. Toxicol Appl Pharmacol 243: 63-67, 2010.

41. Reiners JJ Jr, Lee JY, Clift RE, Dudley DT and Myrand SP: PD98059 is an equipotent antagonist of the aryl hydrocarbon receptor and inhibitor of mitogen-activated protein kinase kinase. Mol Pharmacol 53: 438-445, 1998.

42. Perdew GH: Association of the Ah receptor with the $90-\mathrm{kDa}$ heat shock protein. J Biol Chem 263: 13802-13805, 1988.

43. Meyer $\mathrm{BK}$ and Perdew GH: Characterization of the AhR-hsp90-XAP2 core complex and the role of the immunophilin-related protein XAP2 in AhR stabilization. Biochemistry 38: 8907-8917, 1999.

44. Heid SE, Pollenz RS and Swanson HI: Role of heat shock protein 90 dissociation in mediating agonist-induced activation of the aryl hydrocarbon receptor. Mol Pharmacol 57: 82-92, 2000.

45. Refat NA, Ibrahim ZS, Moustafa GG, Sakamoto KQ, Ishizuka M and Fujita S: The induction of cytochrome P450 1A1 by sudan dyes. J Biochem Mol Toxicol 22: 77-84, 2008.

46. Lubet RA, Connolly G, Kouri RE, Nebert DW and Bigelow SW: Biological effects of the Sudan dyes. Role of the Ah cytosolic receptor. Biochem Pharmacol 32: 3053-3058, 1983.

47. Dewa Y, Nishimura J, Muguruma M, Jin M, Kawai M, Saegusa Y, Okamura T, Umemura T and Mitsumori K: Involvement of oxidative stress in hepatocellular tumor-promoting activity of oxfendazole in rats. Arch Toxicol 83: 503-511, 2009. 